\title{
Political Competition and the Diffusion of Conditional Cash Transfers in Brazil
}

\author{
Denilson Bandeira Coêlho \\ Political Science Institute, University of Brasília
}

\begin{abstract}
What factors determine the diffusion of social policies? This article examines the launching of conditional cash transfer programs by Brazilian municipalities to explore this problem. The literature of political science asserts that such programs have been widely implemented because they correspond to an alternative policy strategy adopted by governments facing opposition to implement universal public policies. So, political competition would be at the root of CCT launching. This article presents an alternative explanation. From 1995 to 2001, local governments created or emulated the Bolsa Escola Program (BEP) in all regions of the country. Such a path continued after the lauching of the national Bolsa Escola by the federal government. Why did some local governments decide to adopt the national BEP and others did not? To answer these questions, the research tests the influence of structural, internal and external variables on the dissemination of CCT programs. Two main hypotheses are tested. The first asserts that local political competition is positive for policy diffusion. The second hypothesis claims that party alignment between the municipal and federal levels increases the likelihood of municipalities adopting the federal BEP. The research uses Event History Analysis to test statistically the impact of political incentives on policy diffusion among São Paulo State's municipalities. Two types of policy diffusion are examined: horizontal and vertical. The findings confirm that political competition influences the horizontal diffusion among municipalities. Unexpectedly, vertical diffusion does not occur because of party alignment or political competition. Rather, levels of socioeconomic development drive policy emulation.

Keywords: policy diffusion; political competition; local government; conditional cash transfer programs
\end{abstract}




\section{Introduction}

The launching of innovations in social policies by municipalities in Brazil was largely expected as a result of the emergence of new political parties and the flourishing of participative bodies at the local level. What is surprising is the fact that local social programs spread broadly in the country during a specific period when many social policies were also being offered by states and the central government. Experiences such as the Participatory Budgeting, Family Health Program and Conditional Cash Transfers ${ }^{1}$ are good examples of local innovation that spread out among municipalities. Understanding the origin and diffusion of innovative public policies are the goals of this article. More specifically, the object of this study is the Bolsa Escola Program, implemented for the first time in 1995 in Campinas (SP) and Brasília (DF). The main goals of the program were to fight poverty and, simultaneously, to broaden the coverage of education ${ }^{2}$ by transferring cash directely to participant families. The path of Bolsa Escola expansion among Brazilian municipalities began in 1995 and lasted until 2001. In this period, the federal government also created two national programs: the Minimum Income Guarantee Program (Programa de Garantia de Renda Mínima - PGRM) in 1997, and the Bolsa Escola Federal ${ }^{3}$ in 2001. The former was implemented in 1,350 municipalities and the latter was present in almost all cities in the country from its first year.

The main difference between the municipal programs and the two versions of its federal counterpart relates to their respective funding arrangements. In the case of municipal Bolsa Escola, the local government was in charge of funding. In the first period of the federal programs, cash transfers made to beneficiaries came from a joint federal and municipal fund, while in the second period it was funded exclusively by the federal government. After the implementation of these federal programs, it was expected that local governments would no longer be responsible for local policies of cash transfers. Nonetheless, hundreds of municipalities from the five geographic regions of Brazil followed the experience undertaken in Campinas and Brasília. ${ }^{4}$ Deeply diverse in terms of population, poverty levels, economic weight and political system, many municipalities decided to fund the same program, an event that occurred in a relatively short period of time. The expansion of an identical policy model among municipalities is intriguing and raises important questions for public policy research agenda. The present study of minimum income diffusion in Brazil is relevant to identify the directional mechanisms for policy adoption such as emulation across municipalities and emulation as a top-down process.

To explain the phenomena of the diffusion of innovations that originate from domestic processes and experience multiple directions, the present article examines the case of the state of São Paulo, a jurisdiction where approximately two hundred municipalities 
administered by different political parties adopted the programs of Bolsa Escola at the municipal level and/or the PGRM between 1995 and 2001.

In theoretical terms, the approach adopted in this study is rooted in the policy diffusion and political competition literature, with special emphasis on the incentives actors are exposed to when creating and reproducing innovative ideas. This theoretical approach differs greatly from those traditionally used in the domestic literature. In Brazil, the process of implementing public policies is studied largely from the perspective of federalism, with emphasis on intergovernmental relations and the positive and negative features of decentralization (Draibe 1998a, 1998b, 2004; Arretche 2000, 2004; Abrucio 2002, 2005; Souza 1997, 1998; Melo 1996; Samuels 2004). Despite the essential contributions to the understanding of a set of specific questions provided by this body of literature, an analysis of the policy diffusion process in developing countries like Brazil is non-existent. In a review of public policy research, Faria (2003) confirmed the lack of analyses focused on policy diffusion in Brazil. Accordingly, the traditional approaches of the specialized literature appear limited. When focusing on the role of the central government and its institutional capacity to implement public policies, scholars tend to minimize factors such as local political competition, economic development, and the regional effects of geographic proximity, which are very important to explain the origin and path of public policies. The theoretical and empirical approaches of social policy diffusion involving cash transfers have not been yet incorporated into these analyses. Only a few exceptions to this rule are evident, as the study by Sugiyama (2007) on the diffusion of the programs Bolsa Escola and Saúde da Família ("Family Heath Program"), some theoretical and empirical contributions by Melo (2004, 2007) concerning the diffusion of pro-poor programs in Brazil, and by Wampler (2005) about the diffusion of participatory budgeting.

\section{Theoretical Approaches and Policy Diffusion}

The classical problem in the study of patterns of ideas and policy diffusion is to understand who adopts an innovation, how this occurs and what is the pace of this phenomenon. ${ }^{5}$ In addition to these main questions, others emerge in different fields of study. In the context of the diffusion of cash transfer programs in Brazil, the following questions are crucial: why did municipal governors emulate policies from other municipalities? Why some mayors did not adhere to federal policies and created new social programs? Why did certain emulated policies spread quickly and others not? These are key questions that the literature on social policy diffusion, well recognized by national and international comparative studies, should investigate to better understand the puzzle of local policy-making process. The current body of work has been based on three rival theoretical notions to 
identify the factors that engender policy diffusion: political incentives, ideology, and social network. The approach that considers political incentives to be the most relevant is based on rational choice theories. ${ }^{6}$ According to this approach, individuals make rational choices seeking directly their political survival. The strategy adopted aims at minimizing costs and maximizing their own benefits, taking into account the selection of policies among all other existing alternatives. The seminal study by Downs (1999) explains the strategic behavior of political actors in competitive electoral environments. The author considers that individuals' rational behavior essentially meets their own interests. ${ }^{7}$ In the context of policy diffusion, the specialized literature indicates that individuals create or emulate programs in order to obtain political credit from the electorate. According to Palloni (2001:71), "the vast majority of the applications of diffusion models in the field of demographic and sociological studies neglects a basic principle: adopters and non-adopters are rational decision makers and the adoption is the result of a rational decision making process". The work of Keefer and Khemani (2003a, 2003b), analyzing the competition for innovative policies, demonstrates that the stronger the electoral competition between parties is, the more likely the parties will attempt to propose new social programs. In this scenario, the parties' goal would be to distinguish themselves from others, seeking to be identified as reformers. Therefore, municipalities, states or countries with high levels of electoral alternation tend to create or adopt new policies. From this perspective, it is expected that BEP and PGRM will be emulated more often in cities with highly competitive mayoral election races. In short, the hypothesis is that the increased provision of welfare to vulnerable groups of the population increases the chances of political reelection.

According to the theoretical approach focusing on the question of ideology, political actors would be more interested in making decisions based on their trust in social change, with no concern about particular gains. Mullins (1972) considers that the ideological division between right and left does matter, and guides the evaluation of the implementation of certain social policies. From this point of view, left-wing politicians are guided by personal and moral values, being able to make decisions against their own interests. Analyzing the policy diffusion dynamics in America, Boushey (2010) suggests that more liberal progressive states will be more receptive to policy innovation, and conservative traditionalist states will remain entrenched and resistant to policy change. From this theoretical perspective, since the BEP and the PGRM represent an institutional innovation both in terms of policies to combat poverty and in terms of extending social rights, it is likely that political actors from left and center-left parties will become more active in emulating these programs, in connection with their ideological beliefs. In recent elections, parties located on this side of the ideological spectrum vindicated that the State must reconfigure the welfare network through minimum-income programs. As the literature points out, the 
ideological positioning of Brazilian parties does not present strong variations over time. Using the categories of Mainwaring (1999), and Power \& Zucco (2009) which converge by positing PT and PSDB as left and center-left parties, the present work tests the role of the main parties that compete for the paternity of the minimum-income model in Brazil.

For social network theory, actors and institutions under similar social structures tend to adopt the same professional rules and to reproduce their partner's acts. For Abrahamson (1991, 1996), adopting policies is related to the existence of trends among the members of a certain social network. By studying the regional effects of the diffusion of state policies, Mooney (2001) reaffirmed the findings of Walker (1969) and validated the importance of informal networks, understood as arrangements that bring political and social actors closer, geographically speaking. In the studies of diffusion, this type of analysis is denominated as "spatial proximity". A classical consensus of researches on diffusion is that the spatial proximity among actors can result in a stronger political influence in connection to personal or cultural links. Even though Brazil and São Paulo state have an institutionalized network of public policies, there are no empirical evidences sustaining that a political or a non-governmental organization have provided support to the dissemination of the Bolsa Escola Program. Following such a perspective, and based on a spatial diffusion-model, this study tests the influence of informal mechanisms such as facilitated communication and the frequency of interactions among political actors that are geographically close to each other.

The study conducted by Sugiyama (2007) was the first to critically discuss the three rival theoretical approaches in order to identify the factors that engender policy diffusion. The study on the diffusion of Bolsa Escola and Programa de Saúde da Família ("Family Health Program") in Brazil produced interesting results. The main goal of the research was to investigate the factors that caused the recent diffusion of policy innovation among Brazil's geographic regions. To accomplish this, the three rival theoretical models were tested in order to identify the individual motivation that led political actors to emulate the programs. The latter two approaches, ideology and social network, are connected to sociological theories. They consider the actors' ideology ${ }^{8}$ and their participation in networks as factors that are likely to stimulate the reproduction of programs. The results of the statistical model and the qualitative analysis demonstrated that the variable "political competition" did not explain the diffusion. The study concluded that the actors' participation in networks, as well as their ideological position, are factors that influence the dissemination of innovative programs. However, from the conceptual and methodological point of view, the study failed when it dealt with both BEP and PGRM as the only phenomenon that needed to be explained. The justification was based on the comparability of two dimensions: institutional design and programmatic objectives. ${ }^{9}$ Such a conceptual 
interpretation leads to a methodological mistake as the effect estimation of the covariables on the dependent variable is biased. It is not possible to estimate precisely, in the same statistical model, the effect of political competition on the creation of local programs and adherence to federal ones, as actors' political incentives differ and are directly connected to financial and political costs. In sum, the study provided a relevant contribution to the literature on policy diffusion, and opened a new research field in Brazil.

To conclude, these theoretical approaches differ from each other both in conceptual terms and in the definition of the factors that motivate politicians to emulate policies. However, although this divergence is valuable for theoretical analysis, a common factor should be considered in the study of policy diffusion: the costs of reproducing a program from another jurisdiction. These costs, for instance, the enforcement of law and administrative procedures, personnel training, and program functioning, result in political unease for political actors and cannot be disregarded in comparative and case studies. Therefore, the present study takes the rational calculus of actions' costs versus benefits that can be obtained as the central variable to be tested in order to investigate the reasons that lead a political actor to emulate social sector innovation. From this perspective, the ideological formation of an actor, or the social network in which they belong are important but do not matter as much as political incentives to explain the implementation of a social policy. Based on this theoretical understanding, this study encompasses an analysis based on an empirical investigation of the political incentives that motivate politicians to emulate cash transfers policies. In this article, political incentives are considered in two different dimensions due to the features of the programs analyzed, as well as their specific diffusion patterns. In the case of horizontal diffusion among municipalities, political incentives are analyzed according to the level of electoral competition. The more intense the local competition, the stronger a mayor's incentive to create policies that will increase their reelection chances. For vertical diffusion between central and municipal levels of government, the political incentives are analyzed based on the competition for federal budget resources, so mayors politically aligned to the president's party will have more incentives to adopt national policies, regardless of existing adherence rules. ${ }^{10}$

\section{Methodology}

The focus of this article rests in a case study of São Paulo. ${ }^{11}$ The study employs the Event History Analysis (EHA) methodology. EHA is used by many authors interested in understanding the conditions that determine the continuity of a certain phenomenon over time. Researches that make use of EHA can work with either quantitative or qualitative data, or even with the two combined. In order to have a reasonable explanation of the 
factors that led mayors to create BEP and to adhere to PGRM, this study employs a mix of approaches. The analysis of the determinants of these motivations required, in addition to qualitative research, the use of probability-statistical models. These were models of survival or risk analysis and the logit model. In the international literature, survival models can appear under different names: survival analysis, duration models, survival models, reliability models and failure-time models (Box-Steffensmeier and Jones 2004a). The application of statistical models in EHA methodologies is used in order to estimate the probability that a specific event will occur over time. Traditionally, EHA was applied to case studies with small unities of analysis (small- $N)$. More recently, studies with large $N$ started to be covered by the literature. King et al. (1994) affirm that analyzing a larger number of cases allows one to establish a consistent causal inference between variables. Box-Steffensmeier and Jones $(1997,2004 b)$ corroborate this by affirming that the employment of statistical analysis across a large number of cases can generate improved confidence in the results. Berry and Berry (1990, 1992, 1999), and Collier and Messick (1975) emphasize that the model allows a more robust analysis of the internal and external aspects of diffusion, which in turn makes the entire research project more consistent.

The EHA model allows testing both the internal and regional effects by using time-series cross-sectional data. The main advantage of using EHA to study the diffusion of policies is that the model captures the temporal characteristics of changes by using data such as the time, the quantity of cases, the sequence and the duration of events (Box-Steffensmeier and Jones 1997). Researches that use EHA have a focus, therefore, on the processes of change over a course of time with temporal longitudinal data, with a strong emphasis on the dynamic of temporal structure in clear substitution to researches focused on traditional cross-sectional methods. Compared to other models, the methodological advantage of EHA is that the method allows to estimate more precisely the influence of factors that determine the political change over time. A crucial difference is that EHA identifies the timing of the political change by demarcating the periods in which the events took place. Thus, the model properly controls the study of dynamic processes through a technique that is also dynamic. As its theoretical-methodological proposal, the article presents how EHA can be used to investigate recent diffusion-phenomena in Brazil based on a design of empirical research that incorporates both the internal and regional determinants influencing the diffusion of BEP. In sum, the application of EHA makes it possible to measure the effect of internal (political competition, ideology, economic development, etc.) and external (social or political networks by means of geographical proximity) variables. 


\section{The Diffusion of the Municipal Bolsa Escola Program}

The emergence and the emulation of social programs led by local governments is a rare event in the Brazilian political system. One of the aims of this study is to describe how the bandwagon-effect of Bolsa Escola Program took place in São Paulo, based on diffusion theories. The literature does not stipulate a minimum number of cases for categorizing a diffusion-phenomenon. Instead, it establishes a few points of consensus, such as: a similar adoption of aims, instruments and implementation styles. Another characteristic is that the emulation of the program is expected to take place in a relatively short period of time. Based on the specialized literature, this study identifies sufficient properties for classifying the emulation of BEP in the state of São Paulo as a phenomenon of policy diffusion. The São Paulo municipalities have replicated similar institutional designs for a period of seven years in an environment characterized by the absence of coordination of political institutions and pressure by non-governmental organizations. The decision of emulating BEP was interconnected with previous decisions of other governments, marked by informal interaction among the pioneers and the copiers. From this perspective, as defined by Elkins \& Simmons (2005), the diffusion process has taken place in an uncoordinated but interconnected way.

In other regions of the country, the launching of the program was also an independent decision of each jurisdiction. The adoption of similar objectives in the cases of Campinas and Brasília and peer-learning - political parties with analagous programs and contents - indicate that there was indeed an interconnection among the cases. In all regions of the country, the model was also emulated by municipalities administered by different political parties. These municipalities vary significantly in terms of population size and in economic and social indicators, so it is intriguing that the objectives and the style of implementation of the policy were quite similar. The following data illustrate the dynamism and the specificity of the Brazilian case.

Table 1 shows the distribution of municipal proposals for the creation of Bolsa Escola by political parties across Brazil. The survey shows that 61 per cent of the 90 proposals had a PT authorship while PSDB originated approximately 13 per cent of the proposals. The result shows that PT had a leading role in initiating proposals, along with its attempt to dominate politics. 
Table 1. Municipal proposals of Bolsa Escola Program by Political Party -

Brazil (1995-2001)

\begin{tabular}{ccc}
\hline Political Party & Number of proposals & \% \\
\hline PT & 52 & 57.7 \\
\hline PSDB & 11 & 12.3 \\
\hline Other Parties* & 9 & 10.0 \\
\hline No party affiliation & 1 & 1.1 \\
\hline More than one party & 6 & 6.7 \\
\hline Popular initiative & 1 & 1.1 \\
\hline Missing Information & 10 & 11.1 \\
\hline Total & 90 & 100 \\
\hline
\end{tabular}

Source: Author's calculations based on NEPP/UNICAMP/UFMA and IPEA.

*PPB, PSB, PTB, PMDB and PFL.

Table 2 shows the distribution of municipal proposals for Bolsa Escola. The state of São Paulo has 53 of the 90 proposals (59 per cent of the total). These data indicate that concerning the proposal of innovative policies, the state of São Paulo is quite distinct from the rest of the country. Moreover, the table indicates that the number of São Paulo proposals is partly associated with the number of proposals presented by PT.

Table 2. Municipal proposals of Bolsa Escola Program in São Paulo and other States (1995-2001)

\begin{tabular}{ccc}
\hline State & Number of proposals & \% \\
\hline São Paulo & 53 & 59.0 \\
\hline Other States & 9 & 41.0 \\
\hline Total & 90 & 100
\end{tabular}

Source: Author's calculations based on NEPP/UNICAMP/UFMA and IPEA.

The number of programs effectively implemented by municipalities between 1995 and 2001 shows that the state of São Paulo leads with more than half (51 per cent) of the programs. In terms of region, 80 per cent of the cases are concentrated in the south and southeast, and the other regions comprise 20 per cent. This result reinforces the findings that São Paulo stand out from other states. Two factors play a role in explaining the strength of São Paulo in fostering Bolsa Escola Program: first, the fact that PT governed a larger number of city halls in this state, compared to the rest of the country; second, the importance of Campinas as a pole city that influenced the neighboring cities.

Figures 1 and 2 graphically illustrate the development of BEP's diffusion in the state of São Paulo. In Figure 1, it is possible to notice that the pattern of diffusion is not stable over the years, oscillating up and down , including years of no program creation (1998, 
2000). Authors like Lowi (1963) and Walker $(1969,1973)$ argue that the first years of a program are more likely to witness the creation of new programs, either because the motivations to innovate are stronger or because political campaign promises begin to be carried out. In the specific case of BEP, the years of 1997 and 2001 witnessed the approval of, respectively, six and two programs. Considering that in the first year, five municipalities created the program and in 1996 ten extra municipalities did the same, it would be expected that in 1997 this number would increase. In 2001, when PGRM had already been in execution since 1999 and BEP since April, it would be reasonable to expect municipalities to adopt the federal program. Moreover, the fact that 1996 was the year in which the largest number of municipalities copied the program and, at the same time, in 2000 there were no new cases registered, suggest that these last years did not provide sufficient incentives for the creation of new policies.

Figure 1. Adoption of Bolsa Escola Program by Municipal Government in São Paulo State (per year)

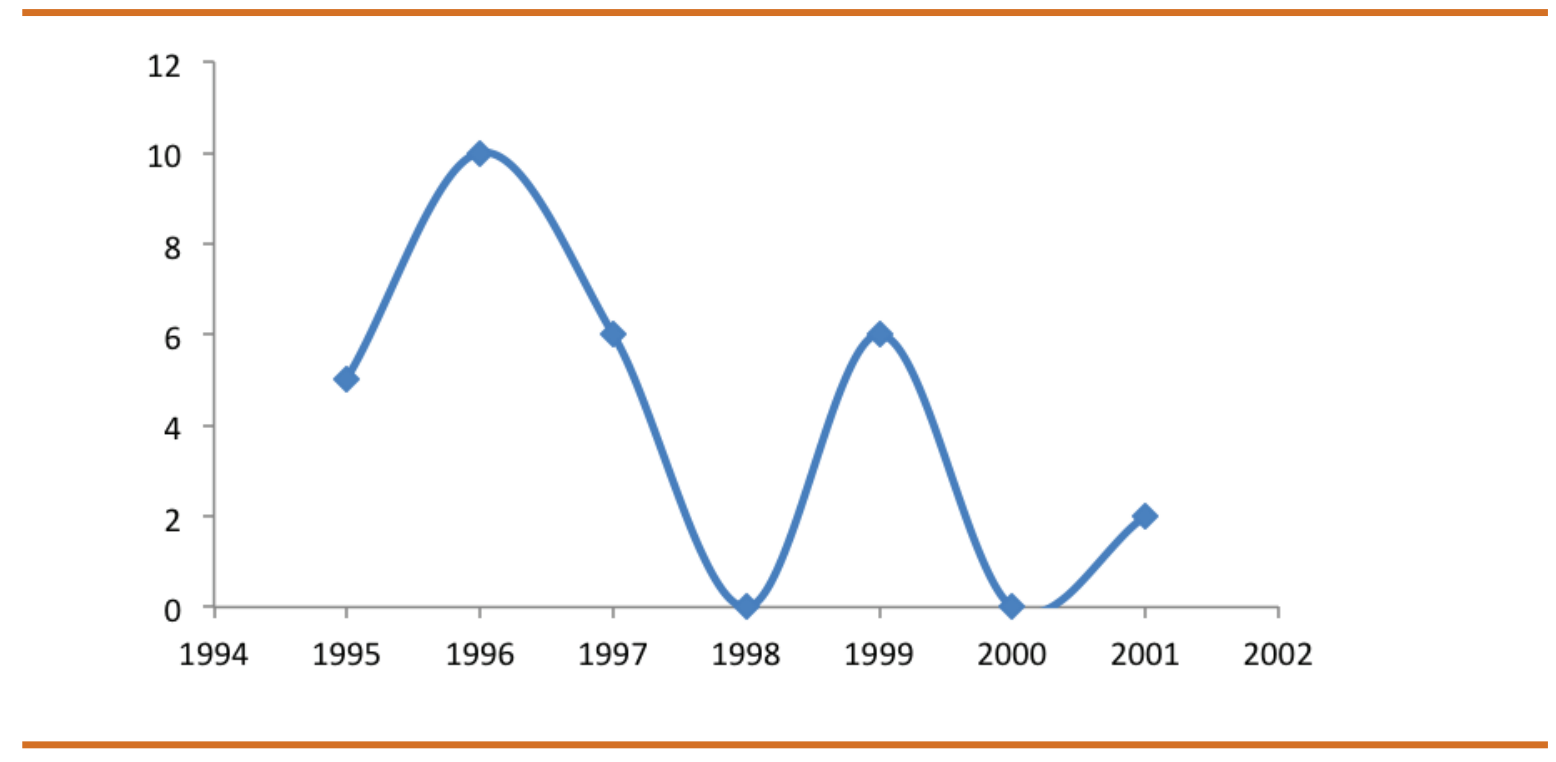

In Figure 2, it can be observed the cumulative evolution of BEP over the last three cycles of municipal government. In the first period, the first 15 cases appear. In the second, 12 extra cases are registered and in the last one, two other cases are observed. The cumulative adoption over time is often interpreted in the literature as an S-shaped curve that follows a frequency distribution showing a slow pace at the first stage, followed by faster growth and then a decrease at the last moment (Rogers 1995; Stocking 1985; Mohr 1987). The cumulative distribution, which demonstrates BEP's path between 1995 and 2001, can be interpreted in two ways. In the first case, the adoption rates reflect one of the types of S-shaped distribution. In the second case, the emulation of the programs is similar to the classic form of S-shaped distribution. The results of the distribution, shown in figures 1 
and 2, define two important dimensions of the diffusion process: the path of the program and the rate of the program adoption over time as well as the profile of actors who tend to copy innovative policies.

Figure 2. Cumulative Adoption of Municipal Bolsa Escola in São Paulo State

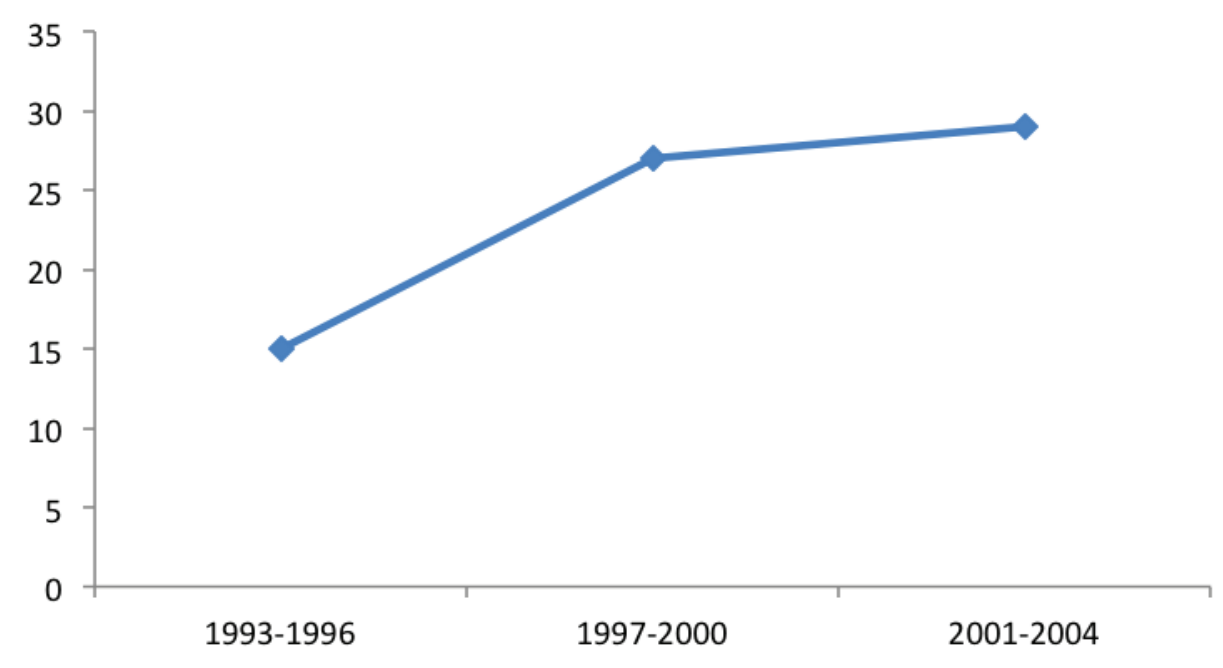

\section{The Diffusion in São Paulo: an Event History Analysis}

This section analyzes the influence of internal and structural determinants on the probability that São Paulo's municipalities copy BEP. In order to estimate, the statistical methodology of EHA, which assess the risk that a specific event will occur in a given period, is used. In the particular context of BEP's diffusion, the model of Survival Analysis is applied with the purpose of measuring the probability that a given municipality would take the initiative of adopting a program from another municipality from 1995 to 2002. Survival models differ from other kind of regressions due to two characteristics. The first is that this kind of model deals with censored data, which is only partially observed due to the end of the research, lack of information and/or random failure. The second difference is that the independent variable can have its value changed during the observation period, which makes the analysis more reliable. The Survival Analysis applied in this study is the Proportional Hazard model by Cox. The model relates the dependent variable to covariables (hazard factors) that are likely to be associated with the failure or occurrence of an event.

\section{Description of Cox's Proportional Hazard Model, Variables and Hypotheses}

The data organization for the analysis of BEP was undertaken with the support of the statistical package STATA.12 The statistical model of Survival Analysis will be used 
in order to allow for the probabilistic interpretation of the risk of municipalities to create BEP. In this study, the model will test what factors increased or decreased the probability of a given mayor to create BEP in the periods of 1995 and 2002 - respectively: the starting point of the program being Campinas and the first year that no program was created. Cox's proportional hazard model attributes a hazard function $\mathrm{h} 0 \mathrm{t}$ ) to all individuals. The $\mathrm{b}$ are regression coefficients that estimate the effect of the covariables on the failure rate. Therefore, b coefficients represent how much a specific covariable increases or reduces the risk of copying BEP. The model's equation is specified as follow:

- $\underline{\text { Model: }}$ Adopting BEP $=1 \mathrm{n}(\mathrm{Pi} / 1-\mathrm{Pi})=\alpha+\beta 1$ (municipal political competition) + $\beta 2$ (municipality governed by PT) ${ }^{13}+\beta 3$ (municipality governed by PSDB) ${ }^{14}+\beta 4$ (geographical proximity) $+\beta 5$ (metropolitan municipality) $+\beta 6$ (transfers from the government to poor families) $+\beta 7$ (GDP per capita) $+\beta 9$ (municipalities with large population) $+\beta 10$ (municipalities with medium sized population).

\section{The Dependent Variable}

The research comprises 645 municipalities of São Paulo state. In order to estimate the effect of covariables on BEP's diffusion, the data reveals the year when the program was copied and by which municipality. The dependent variable is coded dichotomically, with " 0 " attributed to municipalities that did not create a BEP and " 1 " to those that have. When an event occurs, that is, when a municipality creates a BEP, the year of creation is registered and the municipality is not reported for the subsequent years. ${ }^{15}$

\section{Independent Variables}

The statistical model used in this study will test the effect of a set of independent variables that are associated with internal and structural factors of the phenomenon analyzed. The covariables nature according to the determinant and control factors is specified as follows:

\section{Municipal Political Competition (MPC) $)^{16}$}

The main independent variable of the model is municipal political competition. The literature identifies political competition as a robust determinant of policy diffusion. One of the findings of Walker's seminal work (1969) on policy diffusion among American states in the 1960s was that competitive electoral systems are more likely to emulate a policy in comparison to less competitive or noncompetitive electoral systems. Following this argument, the municipalities that have greater electoral competition are expected to be more likely to emulate Bolsa Escola than those municipalities with less competition.

- Hypothesis 1: In political systems, at the municipal level, the larger the electoral competition, the higher the probability of creating Bolsa Escola. 
Municipalities governed by PT (MUNPT) and by PSDB (MUNPSDB $)^{17}$

The second group of determinants to be tested were those associated with the role of political parties on policy diffusion. Political parties create new social programs aiming to obtain credibility from certain electoral groups and also from the society as a whole (Keefer 2005). In the context of BEP dissemination, PT and PSDB were the parties responsible for developing the program in Brazil. Aligned with this perspective, this paper tests whether or not BEP emulation is associated with the administration of the two parties.

- Hypothesis 2: municipalities governed by PT are more likely to copy BEP in comparison to municipalities governed by other political parties.

- Hypothesis 3: municipalities governed by PSDB are more likely to copy BEP in comparison to municipalities governed by other political parties.

\section{Geographical proximity (GEOPROX) ${ }^{18}$}

The fourth variable in the model refers to the neighborhood effect or geographical proximity among municipalities. As observed by Walker (1969) geographical proximity can have an impact on the policy diffusion process. This phenomenon is due to the dissemination of ideas that occur in events related to public policies, like conferences, seminars, political party meetings, or in the media. With this approach, the circulation of information on policy innovation would first reach closer territories. Therefore, municipalities located close to a municipality that has created a new program would tend to reproduce their neighbor's experience more often than municipalities from more distant regions.

- Hypothesis 4: the closer the geographical proximity to municipalities that have created Bolsa Escola, the higher the probability that a municipality will copy its neighbors' idea.

\section{Metropolitan Municipality (METMUN $)^{19}$}

The fifth variable in the model also estimates the effect of geographical proximity. However, there are two important features that distinguish it from the last variable presented here. The first is the location of municipalities in innovative regions, that is, areas that innovate more in terms of offering public policies in contrast to less creative areas. The second feature relates to the importance of what could be called "model cities" of metropolitan areas, seen as a reference and example to be followed. The literature that deals with this question argues that there is a link between the "pioneers" and the "emulators", where the element of spatial proximity is an essential element for program emulation (Walker 1969; Elazar 1972). In their comparative investigation about the implementation 
of policies in the North American federalism, these authors noticed that the most similar states in economic and social terms tended to emulate their nearest neighbors through the identification of common problems and the possibility of achieving positive effects. Even though the emulation-requirements are the position as a neighbor and the similarity among the federative units, the theory of social networks on policy diffusion has conceived two contending views in regard to the communication channels. The fixed-region view presupposes that potentially all units adopting a program in a region have the same information and are formally and informally influenced by networks. In contrast to it, the neighborhood-effect view affirms that each unit is influenced by a specific group of neighboring territorial units, which are not necessarily of the same region. Following Foster's (1978) view of follow-the-leader phenomenon, this work considers that BEP is probably more emulated at metropolitan regions because of the influence of model cities like São Paulo, Campinas and Santos.

- Hypothesis 5: metropolitan municipalities are more likely to copy Bolsa Escola than non-metropolitan municipalities.

\section{Control Variables}

Other variables used in the model are Transfers from the Government to Poor Families (TRANSFGOVFAM) ${ }^{20}$ and GDP per Capita (GDPperCAPITA). ${ }^{21}$ Regarding the first variable, this work builds on the studies of Mossberger (1999), and Welch \& Thompson (1980), to investigate the influence of federal transfers in the adoption of innovative policies. Even though in this particular case the fiscal incentives are not directly targeted at BEP, I assume that the higher is the level of welfare dependence of poor families, more likely mayors will use federal resources to adopt new programs to confront poverty. With the variable GDPperCapita, I seek to control the possible effect of a municipality's economic development level on its choice to adopt the program. Population size is a factor that potentially affects the diffusion of Bolsa Escola and is used in the model as a control variable. Due to the great diversity of population size of the municipalities studied, ${ }^{22}$ and considering this variable is not linear, the units were grouped in three categories according to the size of their population: small, medium and large. The classification by population size was defined according to IPEA, which uses the following criteria: small municipalities have up to 100.000 habitants, medium size municipalities between 100.001 and 500.000 habitants and large municipalities 500.000 habitants or more. ${ }^{23}$ The effect of municipalities of medium and large populations on the dependent variable will be tested. These last two categories have greater institutional and fiscal capacities and, as a consequence, are more likely to create or copy new policies. 
This group of variables encompassing internal determinants of Bolsa Escola diffusion in São Paulo state provides important elements in explaining the phenomenon under analysis. However, the selection of variables in statistical models is a complex task due to two main complementary reasons. The first is that the choice of variables must be made through the use of analytically relevant criteria. The second relates to the exclusion of omitted-variables that could provide a statistical result that is more robust and accurate. Like any other academic work, the present study, when using a statistical model to define the causal relationship between variables, can be omitting an important covariable. Nevertheless, the applied strategy implies a methodological choice that aims to adjust the statistical model, and to avoid the inappropriate use of variables.

Table 1 presents the results of the statistical tests that reveal the effect of the determinants on the probability of local governments to create/emulate Bolsa Escola. The first four regressions showed in the table include a mix of variables of the study. In the last regression, the covariables PT and PSDB were removed from the model in order to estimate the effect of political competition without controlling by the effect of political parties. The analysis considers the basic models and aggregates sequentially the covariables, which allows the definition, in a progressive way, of the variation of the effect of political competition on the diffusion of BEP.

\section{Results and Analysis of the Statistical Model}

The result of the first model of Table 3 involves only the first four covariables and defines the coefficients of MPC, MUNPT and MUNPSDB as highly significant. In contrast, the coefficient of GDPperCapita did not prove to be significant. This result suggests that the municipalities' economic level does not alter the decision to copy or not Bolsa Escola. Moreover, this result provides empirical evidence to support a strong correlation between MPC and BEP emulation. In the same way, the result demonstrates that the creation of the program is highly associated with PT and PSDB administrations. 
Table 3. Determinants of the adoption of Municipal Bolsa Escola Program

\begin{tabular}{|c|c|c|c|c|c|}
\hline Independent Variables & 1 & 2 & 3 & 4 & 5 \\
\hline MPC & $\begin{array}{l}3.757 \text { *** } \\
(1.888)\end{array}$ & $\begin{array}{l}3.760 \text { *** } \\
(1.893)\end{array}$ & $\begin{array}{l}3.705^{* * *} \\
(1.862)\end{array}$ & $2.402 *(1.217)$ & $\begin{array}{c}3.282^{*} \\
(1.6661)\end{array}$ \\
\hline MUNPT & $\begin{array}{c}46.94 * * * * \\
(25.03)\end{array}$ & $\begin{array}{c}39.98^{* * * * * *} \\
(23.03)\end{array}$ & $\begin{array}{c}47.75 * * * * \\
(25.61)\end{array}$ & $\begin{array}{c}21.28^{* * * * * *} \\
(13.20)\end{array}$ & \\
\hline MUNPSDB & $\begin{array}{c}59.85^{* * * * * *} \\
(35.16)\end{array}$ & $\begin{array}{c}47.10^{* * * * *} \\
(31.35)\end{array}$ & $\begin{array}{c}59.16^{* * * * *} \\
(34.73)\end{array}$ & $\begin{array}{c}15.21 * * * * \\
(9.219)\end{array}$ & \\
\hline PROXGEO & & $1.733(1.105)$ & & $1.310(.882)$ & $3.239 *(1.822)$ \\
\hline METMUN & & $1.129(.581)$ & & $.612(.331)$ & $.475(.251)$ \\
\hline TRANSFGOVFAM & & & $1.065(.072)$ & $1.124 *(.074)$ & $1.093(.0820)$ \\
\hline GDPperCAPITA & $.999(.000)$ & $.999(.000)$ & $.999(.000)$ & $.999(.000)$ & $.999(.000)$ \\
\hline MUNLarge (population) & & & & $\begin{array}{l}15.34 * * \\
(16.07)\end{array}$ & $\begin{array}{c}77.32^{* * * *} \\
(65.35)\end{array}$ \\
\hline MUNMedium (population) & & & & $\begin{array}{c}10.68^{* * * *} \\
(6.208)\end{array}$ & $\begin{array}{c}15.06 * * * * \\
(8.000)\end{array}$ \\
\hline $\mathrm{N}$ & 645 & 645 & 645 & 645 & 645 \\
\hline Log Likelihood & -133.93 & -133.29 & -133.53 & -123.55 & -136.34 \\
\hline Prob > Chi2 & .000 & .000 & .000 & .000 & .000 \\
\hline
\end{tabular}

Note:***significant at 1\%, ** significant at 5\%, * significant at 10\%. Standard Error in parenthesis.

In the second model, the inclusion of two variables estimating the geographical effect does not modify the general statistical result, that is, it does not alter the influence of MPC, MUNPT and MUNPSDB on the dependent variable. This statistic shows that the decision to copy the program is not directly associated with structural variables and also strengthens the notion that it is not associated with the municipalities' economic situation.

In the third model, when we exclude the two structural variables and include the transfers from the federal government, it is possible to notice that the coefficients of MPC, MUNPT and MUNPSDB remain positive and highly significant. The result again indicates that the coefficients of MPC, MUNPT and MUNPSDB are robust and have a relevant effect on BEP diffusion.

The fourth model includes all variables. Similarly to the last models, the structural covariable GDPperCAPITA do not show statistical significance. However, the variable TRANSFGOVFAM presents a positive coefficient at 10\%. This figure indicates that the socioeconomic condition of the population has partially influenced the decision of emulating BEP. The main variables in the model - MPC, MUNPT and MUNPSDB - confirm their positive effect on the probability of emulating BEP. Moreover, the study shows that in the presence of the control variable "population size", the coefficient of MPC is smaller, and in the presence of GDPperCAPITA the coefficient is bigger. 
Finally, the last model presents the results of Bolsa Escola diffusion without the presence of PT and PSDB. The goal is to estimate the influence of the other covariables on the dependent variable, emphasizing the variation level of the political competition effect, which in the other models was always significant and positive. The results show that two covariables do not present any influence on the dependent variable: METMUN and GDPperCAPITA. For the first time the variable GEOPROX presents a significant coefficient. This result suggests that municipalities with a high level of political competition and not governed by PT or PSDB made the decision of emulating BEP influenced by other municipalities of the neighboring region.

In sum, it can be concluded that the combination of the covariables, as well as the control variables, does not reduce the relevant effect of MPC on Bolsa Escola creation, which confirms the statistical and theoretical importance of this variable on all regressions of the model.

\section{Explaining the Adoption of PGRM in São Paulo}

This section analyzes the influence of potential determinant factors on the probability of São Paulo's municipalities adopting PGRM. The result is obtained through the use of a logit statistical model, which, in the context of this analysis, captures the probability that a given municipality will adopt the federal program in the years of 1999 and 2000, according to a set of political, economic and structural factors. Two models are used to estimate the magnitude of covariables' effect on mayors' decisions. The first model covers internal and structural determinants, and the second takes into account the external factor " $m u$ nicipality selected by the federal government". After the political decision to implement the PGRM, in 1997, the federal government requested a study from IPEA, in order to indicate the poorest municipalities of the country where the resident population needed cash transfers as a complement to the family income. IPEA pointed to approximately 3,300 municipalities in this situation. Due to the high volume of investments that the policy would demand to assist all municipalities in the first year of execution, an arbitrary criterion of selection was used. This criterion consisted of a scheduled execution through which the poorest municipalities were the first to become eligible to PGRM, in an increasing scale that added $20 \%$ of the municipalities per year for each state, until reaching the final point in which all municipalities were included in PGRM. Thus, the program was created to assist on a priority-basis the municipalities with a tax collection per capita and income per capita below the state average. However, as explained by Ana Lobato, ${ }^{24}$ coordinator of the IPEA-study that mapped the situation of the municipalities, there was a strong interference by mayors and governors, who were dissatisfied with the list after it was presented. 
According to governmental managers, ${ }^{25}$ mayors went to the point of presenting their own calculations based on consultancy works and on data gathered by IBGE, in their attempt to delegitimize the technical study of IPEA. Thus, this variable works as a control variable due to its direct influence on mayors' decisions. The main goal here is to analyze, based on qualitative data and statistical results, whether or not the rules of adherence to PGRM altered the process of policy diffusion, once municipalities that were not selected were actually prevented from adhering to the program.

The figures on Table 4 present the adherence to PGRM in São Paulo, listed by political party. As expected, PSDB, as the party with the largest number of municipalities meeting the rules of selection for the program, had the highest rate of adherence. Of the 69 city halls governed by the party, 66 signed agreements with the federal government. The same situation occurred in municipalities governed by PFL and PMDB as second and third places, respectively. Of the 42 municipalities governed by PFL, 35 adhered to PGRM, and of the 32 governed by PMDB, 25 did the same. Together, the three parties added to approximately $75 \%$ of total adhesions to the program. PT was only in office in two municipalities among the 173 eligible to adopt the policy, and one of them adhered to the program.

Table 4. Adoption of PGRM by Political Parties - São Paulo State (1999-2000)

\begin{tabular}{cccc} 
Political Party & $\begin{array}{c}\text { Number of municipalities } \\
\text { apt to adopt PGRM }\end{array}$ & $\begin{array}{c}\text { Number of municipalities that } \\
\text { adopted PGRM }\end{array}$ & $\begin{array}{c}\text { Percentage of municipalities apt to } \\
\text { adopt and that adopted }\end{array}$ \\
\hline PSDB & 69 & 66 & 95,6 \\
\hline PFL & 42 & 35 & 83,3 \\
\hline PMDB & 32 & 25 & 78,1 \\
\hline PPB & 12 & 14 & 116,00 \\
\hline PTB & 10 & 9 & 90,0 \\
\hline PL & 7 & 8 & 114,00 \\
\hline PDT & 7 & 6 & 85,7 \\
\hline PSD & 5 & 5 & 100,00 \\
\hline PSB & 1 & 2 & 200,00 \\
\hline PRP & 4 & 1 & 25,0 \\
\hline PV & 2 & 1 & 50,0 \\
\hline PT & 2 & 1 & 50,0 \\
\hline Total & 195 & 173 & 100,00 \\
\hline
\end{tabular}

Source: Author's calculations based on Ministry of Education and TRE-SP.

Due to the fact that the PGRM was implemented in only two years, it is unnecessary and pointless to draw a graph to describe the yearly trajectory of the program. The 
appropriate illustration in this case is outlined in Figure 3, where it is possible to visualize how diffusion took place in a decentralized way throughout the regions.

Figure 3. Map of the Diffusion of PGRM - São Paulo (1999-2001)

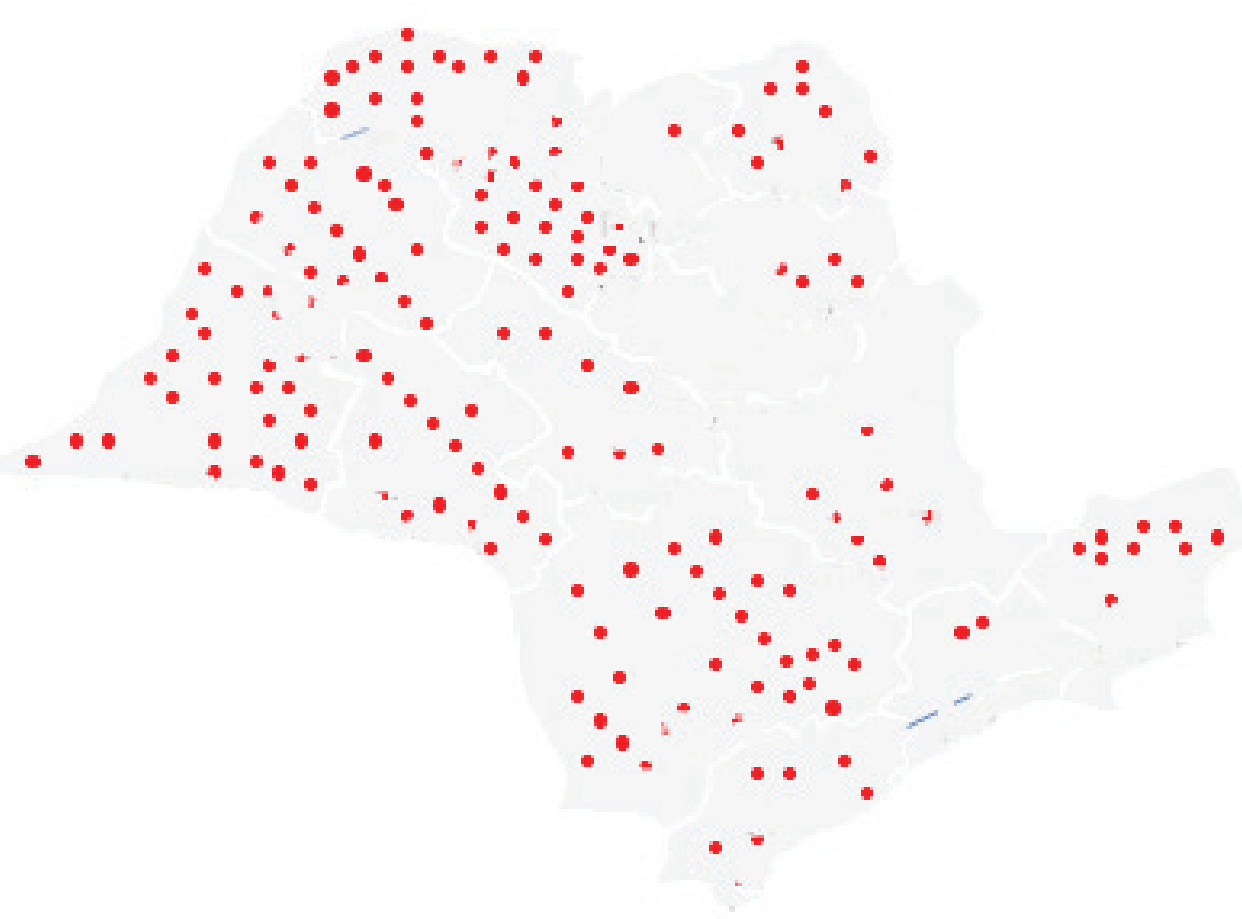

The adherence of municipalities to PGRM and the political strategies of formulation and implementation allow us to categorize the phenomenon of policy diffusion as coordinated and interconnected. The concept, developed by Levi-Faur (2005), defines this type of political process as an action coordinated by certain institutions or party with the power to redesign the provision of public policies. However, due to its rules of selection, which are not stable from the political standpoint, the diffusion-process of PGRM is also characterized as a competitive process, because in practical terms, the chances that a municipality had of adhering to the program affected the chances of adherence by other municipalities. The following section presents a description of the statistical model that was used to analyze the hypothesis testing of the study.

\section{Describing the Logit Model, Variables and Hypotheses}

The logit model allows an estimation of the chances (odds) that a specific event will occur under a group of factors that affects the dependent variable. In this study, the model 
will be applied to test the probability of São Paulo's municipalities adhering to PGRM in the presence of a set of structural, internal and external covariables that potentially affected the decision. Despite the simplicity of the statistical model used, it represents a feasible alternative to explaining the fast diffusion of PGRM in São Paulo state. At the same time, it is prudent to be aware of the fact that the model might not be estimating the most appropriate result concerning the causal relationship between the covariables and the dependent variable. The statistical result, however, will certainly shed light on the problem studied in this paper, which will provide important inferences. The model's equation is described as follows:

- Model: Adopting $\mathrm{RM}=1 \mathrm{n}(\mathrm{Pi} / 1-\mathrm{Pi})=\alpha+\beta 1$ (political alignment with $\mathrm{GF})+\beta 2$ (president's party - PSDB) $+\beta 3$ (municipal political competition) +4 (municipal GDP) $+\beta 5$ (per capita income) $+\beta 6$ (municipality selected by GF).

\section{The Dependent Variable}

The dependent variable of the model, Adherence to PGRM (Ad PGRM), is a dummy with values " 0 " and " 1 ", corresponding respectively to municipalities that did not adhere to the program and to those that did so in the years of 1999 and 2000. The research universe covers all 645 municipalities of São Paulo state. Out of this total, only 195 could adhere to the program in the first two years of program execution due to the rules imposed by the federal government, which selected municipalities according to the criteria of family per capita income in 1991 and per capita self-generated revenues (own tax income) in 1996, both below the state's average. For municipalities that adhered to the program, regardless of whether they were selected or not, " 1 " was considered as the answer.

\section{Independent Variables}

The statistical model used in this study tests the effect of a set of independent variables associated with the internal, structural and external factors of the phenomenon being analyzed.

\section{Political Alignment with Federal Government (POLALIN) ${ }^{26}$}

The main independent variable to be tested in the model is the political alignment between the federal and municipal governments. The literature that deals with this question in all its complexities shows that party alignment between different spheres of government influences the distribution of financial resources in favor of the aligned parties (Cox and McCubbins, 1993). In the context of PGRM diffusion, PT and PDT are considered to be PSDB rivals in the national arena, and, therefore, not politically aligned. The other parties are classified as aligned. Although there are situations in which aligned parties do not 
effectively support the actions of the federal government, they do not have a direct strategy of confronting the president's party. Following this perspective, we seek to test the effect of POLALIN on PGRM diffusion. If the result of the model does not prove the covariable to be significant, it will be concluded that adherence to the program was guided by rigid rules. On the contrary, if the coefficient is statistically significant and positive signed, it indicates that the rules were circumvented by municipalities.

- Hypothesis 6: political alignment between the municipality and the federal government favors an adherence to PGRM, regardless of the adherence rules.

\section{President's party (PARTPRE) ${ }^{27}$}

The covariable PARTPRE is included in the model as it represents one of the dimensions of the political context of PGRM diffusion. Considering the political dispute over BEP between PSDB, the party of the federal government, and PT, it is reasonable to assume that municipalities governed by the former will adhere more to PGRM than municipalities governed by other parties, regardless of the adherence rules. The main goal here is to verify whether municipalities administered by PSDB and not able to adhere to the program were privileged by the federal government. If the statistical coefficient is significant and positively signed, it is evidenced that PGRM diffusion was not guided by existing rules. If the contrary is found, this suggests that diffusion was guided by technical criteria and rules.

- Hypothesis 7: municipalities governed by the president's party are more likely to adhere to PGRM in comparison to municipalities governed by other political parties, regardless of the adherence rules.

\section{Municipal Political Competition (MPC) ${ }^{28}$}

The covariable MPC is employed in the model in order to test the effect of political competitiveness on PGRM diffusion. Although PGRM showed a distinct configuration in relation to BEP, especially due to the fact that the federal government requires the fulfillment of some criteria and was responsible for funding part of the program's costs, its implementation certainly brought political dividends to local politicians that sought their political survival. At the same time, policymakers claim credit for policy innovations in the territory they govern, aiming to increase their chances of political survival (Keefer 2005). Furthermore, even considering that PGRM configuration comprises a relationship from the federal government to municipality government, the decision to participate in the game is the exclusive responsibility of the local executive and it implies a rational calculus 
that takes into account the municipality's electoral competition. Therefore, it is expected that the most competitive units will be more likely to adhere to PGRM than less competitive municipalities.

- Hypothesis 8: the stronger the municipal electoral competition, the more likely municipalities will adhere to PGRM, regardless of the adherence rules.

The other variables included in the model are Municipal GDP (GDPMUN $)^{29}$ and the percentage of children with family income below half the minimum wage (FAMWAGE).$^{30}$ GDPMUN represents an internal determinant highlighted by the literature as likely to alter the diffusion phenomenon as units with larger fiscal and administrative capacity have better institutional conditions to afford the costs of implementing social policies. In the case of PGRM, however, the effect of GDP can be analyzed from another perspective. Due to the rule that focused the program in less economically developed municipalities, it is expected that this covariable will not show any statistical significance. If this result is confirmed, it will be possible to conclude that the program was guided by non biased rules. On the contrary, if it is statistically proven that municipalities that adhered to PGRM were those with higher GDPs, there will be an important sign that the rules were disregarded. FAMWAGE is also a potential internal determinant of PGRM diffusion. This covariable is included in the model because it represents the percentage of children from families that have a per capita income below half the minimum wage at the time the program was implemented. By analyzing the rules and criteria of PGRM, it can be concluded that the program is oriented to benefit municipalities with the largest number of families with poor children. As a consequence, the indicator adopted in the model makes it possible to know whether municipalities with those characteristics were in fact the ones that most adhered to the program. Therefore, it is likely that a statistically significant and positive signed coefficient for this covariable will be found.

\section{Control Variable}

The control variable employed in this study is Municipality Selected by the Federal Government (MUNGOV). This variable is important because significantly increased the chances that a specific municipality adhered to PGRM. Once selected, the mayor just had to accept some requirements of the agreement with the federal government in order to formally adhere to the program. The category of non-selected or selected for the following years implies a situation in which mayors were forced to negotiate the inclusion of their municipalities in the program. As a result, these municipalities' chances of adhering to PGRM were smaller in comparison to the probability of adherence of selected municipalities. Given what has been exposed, it can be concluded that this factor alters the scale 
of PGRM diffusion. Therefore, we performed a test in the logit model that estimated the influence of $M U N G O V$ on the covariables in relation to the dependent variable Adherence to PGRM.

\section{Results and Analysis of the Statistical Model}

Table 5 presents the coefficients obtained from the estimation of internal and external determinants in the two statistical models. The first reports the results of independent variables based on the theories of political competition and political alignment as well as the economic covariables. The second reproduces the results after adding the structural variable MUNGOV, which controls the effect of the other variables on the probability of adhering to PGRM.

Table 5. Determinants of PGRM's Adoption

\begin{tabular}{ccccc}
\hline Independent Variables & \multicolumn{2}{c}{ Model 1 } & Model 2 \\
\hline & Coefficient & Standard Error & Coefficient & Standard Error \\
\hline POLALIN & .203 & .406 & .207 & .424 \\
\hline PARTPRE (PSDB) & .108 & .206 & .152 & .215 \\
\hline MPC (1996) & $-.508^{* * *}$ & .252 & $-.461^{*}$ & .262 \\
\hline GDPMUN & .000 & .007 & .000 & .000 \\
\hline FAMWAGE & $.067^{* * *}$ & .007 & $.039^{* * *}$ & .008 \\
\hline Control Variable & & & $1.486^{* * * *}$ & .230 \\
\hline MUNGOV & & .841 & $-3.423^{* * * *}$ & \\
\hline Constant & $-3.756^{* * * *}$ & & 644 & -302.338 \\
\hline N & 644 & & 0.000 & \\
\hline Prob $>$ chi2 & -323.514 & & & \\
\hline
\end{tabular}

Note: *** significant at $1 \%$, ** significant at $5 \%$ e $*$ significant at $10 \%$.

Model 1 suggests that the political alignment of municipalities with the federal government, or being governed by the same party of the president, do not influence the likelihood of adherence to PGRM. It is possible to partially conclude that the party configuration of the national and municipal level is not part of the explanation of PGRM diffusion. In relation to the variable that tests the electoral competition hypothesis (MPC), it can be verified that its coefficient has statistical significance at $5 \%$, but is negatively signed. Thus, the indices suggest a situation in which the greater the municipal political competition, the smaller the probability of adhering to PGRM. The result is complex and deserves to 
be analyzed carefully. A feasible explanation would be the fact that mayors who govern noncompetitive municipalities will probably be less exposed to the voters' oversight, and, therefore, more likely to adhere to federal programs once they have incentives to manage the offering of welfare services. Moreover, acting in environments with low levels of accountability, ${ }^{31}$ mayors are more prone to adhere to policies funded by other governmental spheres, since if they fail to accomplish the contract's requirements, rival parties would not, in practice, try to use this failure to their own political advantage.

The economic variable GDPMUN does not have any statistical value in the model, revealing a situation in which municipalities' wealth is not an important variable to explain PGRM diffusion in São Paulo state. In this case, the result suggests that the program's rules were in fact enforced and benefited less economic developed municipalities and, in theory, the poorer population. FAMWAGE is the only covariable in the model that shows statistical significance and positive sign. To some extent, the effect of GDPMUN and FAMWAGE together indicates that the program was oriented effectively to benefit the poor population in less economically developed municipalities.

Aiming to test the consistency of the last result's estimates, model 2 includes the control variable MUNGOV. Considering the first three covariables, they remain practically unchanged. The coefficients of POLALIN and PARTPRE remain statistically negligible and do not explain PGRM diffusion. In the presence of the control variable, MPC remains statistically significant and with a negative sign. The covariables GDPMUN and FAMWAGE repeat the previous result. The former proves to be irrelevant, which corroborates the notion that the program has benefited less economically developed municipalities. The latter confirms, once again, the strong correlation with the dependent variable by achieving significance at $1 \%$. As a consequence, it is possible to statistically evaluate that the program did reach the poorer population and was guided by technical criteria. However, as it will be discussed in the conclusion, this result must be complemented by a qualitative analysis.

\section{Conclusion}

This article sought to identify the factors that explain the decision of municipalities to create and adhere to cash transfer programs. The analysis investigated the phenomenon of Bolsa Escola emulation among municipalities and also the municipal governments' adherence to the program created by the federal government that represents an upscaled version of the municipalities' model. Indeed, the strategy of political entrepreneurs aiming to establish minimum income projects at the national level faced strong resistance in the federal arena and also in the sphere of political parties. The political strategy adopted by 
senators Eduardo Suplicy and Cristovam Buarque was one of the factors that determined not only the creation of the program, but also its dissemination over the years. Suplicy (from PT) surprisingly proposed the design of PGRM/Bolsa Escola to José Roberto Magalhães Teixeira (PSDB), who was Campinas' mayor at the time. Buarque, despite not having the support of PT's national leaders, launched a version of BEP in Brasília when he was the governor of the Federal District. The two pioneering experiences were emulated by other municipalities and states, especially those governed by PT and PSDB. Since then, both parties started competing over and claiming credit for the policy.

The dispute between the two parties occurred both in informal (the media) and formal (municipal, state level and national legislative bodies) political arenas. Some evidence that supports this conclusion is the fact that the two parties proposed and approved the largest number of legislative projects aiming at creating new programs. In general, PT demonstrated a higher internal cohesion and promoted the program in more states and municipalities, whereas PSDB implemented federal programs, even though it also sponsored their dissemination across municipalities governed by the party.

The analysis of the policy diffusion in São Paulo suggests that BEP creation is directly associated with the factors Political Competition and Municipalities Governed by $P T$ and PSDB. The covariables' coefficients are positive and statistically significant in all regressions. When the covariables Municipalities Governed by PT (MUNPT) and Municipalities governed by PSDB (MUNPSDB) are excluded from the model, Municipal Political Competition (MPC) maintained high statistical significance. Hence, results confirm the role of local political competition in the horizontal diffusion of innovative social policies. This conclusion is supported by the statistical comparison indicating that program emulation occurred more often in municipalities more politically competitive and governed by PT and PSDB. An important finding of this study is that the geographical proximity does not affect the diffusion of BEP. More specifically, this variable seems to be more important in diffusion processes of less contentious policies.

In relation to PGRM, this study suggests two explanatory factors for the program's adoption at the local level. Firstly, the attention of political elites, which was raised by BEP diffusion. Secondly, the pressure from a group of politicians and parties that aimed to implement the program in their constituencies. The statistical modeling shows that municipalities are governed by Mayors from the President's Party (PARTPRE) or Politically Aligned (POLALIN) with the federal government was not relevant in favoring adherence to PGRM. The variable that estimated the effect of Municipal Political Competition (MPC) did not influence the diffusion of PGRM either. Unlike the case of Bolsa Escola, the probability of adhering to PGRM was higher in noncompetitive political environments. Therefore, the hypothesis that greater rates of adherence to PGRM would be expected in 
competitive environments was not confirmed. However, an important consideration must be kept in mind. According to descriptive analysis, the selection rules were subject to political pressure to benefit the wealthier municipalities, especially by parties aligned with the federal government. This mechanism changed the diffusion of the policy both in São Paulo and nationally. Despite the evidence found in the qualitative analysis indicating that the program was not entirely guided by technical criteria (Amaral 1998; Rocha and Garcia 2001), our empirical evidence suggests that variables related to political incentives are not correlated with the adoption of PGRM: both FAMWAGE and MUNGOV induced local governments to emulate the program. This finding allows us to affirm that the mechanisms that drive the emulation of PGRM across Brazil's cities were guided by formal rules, rather than political criteria.

In sum, based on these results it can be concluded that the phenomenon of BEP diffusion was a process that developed horizontally and, by the time it had created impacts on the political system, it started to develop in a top-down fashion. The article general conclusion is that the nature of political competition is a factor that influences horizontal and vertical diffusion processes. Political competition engenders incentives for the establishment of redistributive programs. Thus, a competitive political environment is associated with a greater propensity for adopting these kind of policies.

However, it is possible to identify different dynamics in horizontal and vertical diffusion. For top-down (that is, vertical) diffusion, the influence of an actor or a group of external actors play an important role. In sum, local political competition matters to a greater extent to horizontal diffusion but to a smaller extent concerning vertical diffusion. In the specific case of PGRM, the external influence is represented by the resources transferred by the federal government. In this case, the influence was so intense that it neutralized other causal factors, including political competition. Federal resources are equally disputed by municipal governments in competitive and noncompetitive environments, even though they have a different rationale.

Revised by Sandra Gomes

Submitted in April 2011

Accepted in December 2012

\section{References}

Abrucio, Fernando Luiz. 2002. "Descentralização e Coordenação Federativa no Brasil: lições dos anos FHC". In: O Estado numa era de reformas: Os anos FHC - Parte 2, editado por Fernando Luiz Abrucio e Maria Rita Garcia Loureiro. Brasília: MP/SEGES.

Abrucio, Fernando Luiz. 2005. "A coordenação federativa no Brasil: a experiência do período FHC e os desafios do governo Lula". Revista de Sociologia Política, n.24, pp.41-67. 
Abrahamson, E. 1991. "Managerial fads and fashions: the diffusion and rejection of innovations". Academy of Management Review, vol. 16, n 3, pp. 586-612.

Abrahamson, E. 1996. "Management fashion". Academy of Management Review, vol. 21, nº 1, pp. 254-285.

Aguiar, Marcelo and Araújo, Carlos Henrique. 2002. Bolsa Escola: educação para enfrentar a pobreza. Brasilia: UNESCO.

Amaral, Carlos et al. 1998. "Programas de Renda Mínima e Bolsa Escola - Concepção, Gestão e Financiamento". Planejamento e Políticas Públicas, Brasília: IPEA, v. 2, p. 4-58.

Andrade, T., Serra, R. 2001. Cidades Médias Brasileiras. Rio de Janeiro: Instituto de Pesquisa Econômica Aplicada - IPEA.

Arretche, Marta 2000. Estado Federativo e Políticas Sociais: Determinantes da Descentralização. Rio de Janeiro: Editora Revan.

Arretche, Marta. 2004. "Toward a Unified e More Equitable System: Health Reform in Brazil". In: Crucial Needs Weak Incentives: Social Sector Reform, Democratization, and Globalization in Latin America, edited by Robert R. Kaufman and Joan M. Nelson. Baltimore: Johns Hopkins University Press.

Berry, Frances Stokes and Berry, William D. State Lottery. 1990. "Adoptions as Policy Innovations: An Event History Analysis". American Political Science Review, vol. 84, nº 2, pp. 395-415.

Berry, Frances Stokes and Berry, William D. 1992, "Tax Innovation in the States: Capitalizing on Political Opportunity". American Journal of Political Science, vol. 36, nº 3, pp. 715-742.

Berry, Frances Stokes and Berry, William D. 1999, "Innovation and Diffusion Models in Policy Research". In: Theories of the Policy Process, edited by Paul. A. Sabatier. Boulder: Westview.

Boushey, Graeme. 2010. Policy Diffusion Dynamics in America. New York: Cambridge University Press.

Box-Steffensmeir, Janet M. and Jones, Bradford S. 1997. "Time is of the Essence: Event History Models in Political Science". American Journal of Political Science, vol. 41, nº 4, pp. 14141461.

Box-Steffensmeir, Janet M. and Jones, Bradford S. 2004a. Event History Modeling: a Guide for Social Scientists. New York: Cambridge University Press.

Box-Steffensmeir, Janet M. and Jones, Bradford S. 2004b. Timing and Political Change: Event History Modeling in Political Science. Ann Arbor: University of Michigan Press.

Collier, David and Messick, Richard E. 1975. "Prerequisites versus Diffusion: Testing Alternative Explanations of Social Security Adoption". The American Political Science Review, vol. 69, No 4. pp. 1299-1315.

Cox, Gary W. and Mathew, D. 1993. Legislative leviathan: party government in the House. Berkeley: University of California Press.

Draibe, Sônia 1998a. "A construção institucional da política brasileira de combate à pobreza: perfis, processos e agenda". Cadernos de Pesquisa, n.34. Campinas: UNICAMP / Núcleo de Estudos de Políticas Públicas. 
Draibe, Sônia et al. 1998b. "Programas de Renda Mínima para Famílias Carentes: levantamento das experiências e metodologia de avaliação". In: Garantia de Renda Mínima: ensaios e propostas. Brasília: IPEA.

Draibe, Sônia. 2004. "Federal Leverage in a Decentralized System: Education Reform in Brazil". In: Crucial Needs Weak Incentives: Social Sector Reform, Democratization, and Globalization in Latin America, edited by Robert R. Kaufman and Joan M. Nelson. Baltimore: Johns Hopkins University Press.

Dolowitz, Davi and Marsch, David. 1996. "Who Learns what from Whom: a Review of the Policy Transfer Literature”. Political Studies, XLIV, pp. 343-357.

Dolowitz, Davi and Marsch, David 2000. "Learning from Abroad: The Role of Policy Transfer in Contemporary Policy-Making". Journal of Policy and Administration, vol.13, n.1, pp. 5-24.

Downs, A. 1999. Uma Teoria Econômica da Democracia. São Paulo: Edusp.

Elazar, Daniel 1972. American Federalism. New York: Thomas Crowell.

Elkins, Zachary and Simmons, Beth. 2005. "On Waves, Clusters, and Diffusion: A Conceptual Framework". Annals of the American Academy of Political and Social Science, 598(1), pp.33-51.

Faria, Carlos Aurélio Pimenta. 2003. "Idéias, Conhecimento e Políticas Públicas: Um Inventário Sucinto das Principais Vertentes Analíticas Recentes". Revista Brasileira de Ciências Sociais, vol. 18, no 51,pp. 21-30.

Foster, John. 1978. "Regionalism and Innovation in the American States". Journal of Politics, vol. 40, pp. 179-187.

Levi-Faur, David. 2005. "The Global Diffusion of Regulatory Capitalism”. Annals of the American Academy of Political and Social Science, vol. 598, pp. 12-32.

Ferejohn, John and Pasquino, Pasquale. 2001. "A teoria da escolha racional na ciência política: conceitos de racionalidade em teoria política". Revista Brasileira de Ciências Sociais, v. 16, $\mathrm{n}^{\mathrm{0}}$ 45. pp. 5-24.

Gerring, John. 1997. "Ideology: A Definitional Analysis". Political Research Quarterly, vol. 50, nº 4, pp. 957-994.

Keefer, Philip and Khemani, Stuti. 2003a. "Democracy, Public Expenditures, and the Poor". World Bank Policy Working Paper, $n^{\circ} 3164$.

Keefer, Philip and Khemani, Stuti. 2003b. "Why do the poor receive poor services?". Economic and Political Weekly, v.39, nº 9, pp. 935-943.

Keefer, Philip. 2005. "Programmatic parties: Where do they come from and do they matter?" Mimeo, The World Bank Development Research Group.

King, Gary, Keohane, Robert, and Verba, Sidney. 1994. Designing Social Inquiry. Princeton: Princeton University Press.

Lowi, Theodore. 1963. "Toward Functionalism in Political Science: The Case of Innovation in Party Systems". American Political Science Review, v. 57, nº 3, pp. 570-583. 
Mainwaring, Scott. 1999. Rethinking Party Systems in the Third Wave of Democratization. Stanford, CA: Stanford University Press.

Melo, Marcus André. 1996. "Crise Federativa, Guerra Fiscal e Hobbesianismo Municipal: Efeitos Perversos da Descentralização?”. São Paulo em Perspectiva Revista da Fundação SEADE, v.10, $\mathrm{n}^{\mathrm{O}} 3$, pp. 11-20.

Melo, Marcus André. 2004. "Escolha Institucional e a Difusão dos Paradigmas de Políticas: O Brasil e a Segunda Onda de Reformas Previdenciárias". Dados - Revista de Ciências Sociais, v. $47, \mathrm{n}^{\mathrm{o}} .1$, pp. 169-206.

Melo, Marcus André. 2007. "Political Competition can be positive: embedding cash transfer programs in Brazil", In: Statecraft in the South, edited by Bebbington, A; W McCourt. London: Palgrave.

Mohr, Lawrence B. 1987. "Innovation Theory". In: New Technology as Organization Innovation, edited by Pennings JM and Buitendam A. Cambridge: Ballinger.

Mooney, Christopher Z. 2001. "Modeling Regional Effects on State Policy Diffusion". Political Research Quarterly, 54(1), 103-124. 2001.

Mossberger, Karen. 1999. "State-federal diffusion and policy learning". Publius, vol. 29, n³, pp. 31-50.

Mullins, Willard A. 1972. "On the Concept of Ideology in Political Science". American Political Science Review, vol. 66, n 2 , pp. 498-510.

O’Donnell, Guillermo. 1991. “Democracia Delegativa?”. Novos estudos, nº 31, pp. 25-40.

Palloni, Alberto. 2001. "Diffusion in Sociological Analysis." In: Diffusion Processes and Fertility Transition, edited by John B. Casterline. National Research Council, Washington, D.C.: National Research Council Press.

Power, Timothy and Zucco, Cesar. 2009. "Estimating Ideology of Brazilian Legislative Parties, 1990-2005: A Research Communication". Latin American Research Review, vol.44, n 1, pp. 218-246.

Rocha, S. and Garcia, E. 2001. O Programa de Bolsa-Escola Federal: uma avaliação do desenho e da operacionalização no período 1998-2000. Relatório para a OIT. Genebra: OIT.

Rogers, E. M. 1995. Diffusion of Innovations. New York: Free Press.

Samuels, David. 2004. "The Political Logic of Decentralization in Brazil". In: Decentralization and Democracy in Latin America, edited by Alfred P. Montero and David Samuels. Notre Dame: University of Notre Dame Press.

Souza, Celina. 1997. Constitutional Engineering in Brazil: the politics of federalism and decentralization. London: Macmillan; New York: St. Martin's Press.

Souza, Celina. 1998. "Intermediação de Interesses Regionais no Brasil: O impacto do federalismo e da descentralização". Dados, v.41, no 3, pp. 569-592.

Stocking, B. 1985. Initiative and Inertia: Case Studies in the NHS. London: Nuffield Provincial Hospitals Trust. 
Sugiyama, Natasha Borges, 2007. "Theories of Policy Diffusion: Social Sector Reform in Brazil". Comparative Political Studies, v.20, nº 10, pp. 1-24.

Villatoro, Pablo. 2005. "Conditional Cash Transfers Programs: experiences from Latin American". CEPAL Review, n 86, pp. 8396.

Walker, Jack L. 1969. "The Diffusion of Innovations among the American States". American Political Science Review, v. 63, n 3, pp. 880-899.

Walker, Jack. L. 1973. "Comment: Problems in Research on the diffusion of policy innovations". The American Political Science Review, v.67, nº4, pp. 1186-1191.

Wampler, Brian. 2005. "A difusão do Orçamento Participativo brasileiro: 'boas práticas' devem ser promovidas?". Opinião Pública, v. 14, nº 1, pp. 65-95.

Welch, Susan and Thompson, Kay. 1980. "The impact of federal incentives on state policy Innovation". American Journal of Political Science, v. 24, nº 4, pp. 715-729.

Weyland, Kurt. 2004. Learning from Foreign Models in Latin American Policy Reform. Washington, D.C: Woodrow Wilson Center Press.

Weyland, Kurt. 2005. "Theories of Policy Diffusion: Lessons from Latin American Pension Reform". World Politics, v. 57, n 2, pp. 262-295.

Weyland, Kurt. 2007. Bounded Rationality and Policy Diffusion: Social Sector Reform in Latin America. Princeton: Princeton University Press.

\section{Notes}

1 Before 1988, some experiences of local innovation in municipalities of the states of Rio Grande do Sul and São Paulo existed. Nonetheless, a large scale process of experimentation occurred effectively from the 1990s on.

2 It is important to mention a particularity of the municipal Bolsa Escola. The target population varied across municipalities: originally, the age cut-off was from 0 to 14 years old. However, the vast majority of the municipalities adopted an age cut-off of 7-14 years old. Furthermore, it is worth highlighting that these cut-offs included both primary and secondary education.

3 Hereafter, the Bolsa Escola programs will be referred to as follows: Bolsa Escola Program (BEP) when referring to the programs created by municipalities, and PGRM and Bolsa Escola Federal when referring to the two programs created by the federal government.

4 Research indicates that between 80 and 200 municipalities created the municipal Bolsa Escola (Aguiar and Araújo, 2002; Villatoro, 2005). However, it is important to note that many proposals were not approved, or approved but not implemented. Moreover, in many cities the state and federal level programs of Minimum Income executed by the municipalities were incorrectly considered as municipal-level programs.

5 For additional information on policy diffusion, see the contributions of Dolowitz and Marsch (1996, 2000); Elkins and Simmons (2005), and Weyland (2004, 2005, 2007). 
6 The classic study by Downs (1999) states that rational choice politics is based on a calculus that takes into account the cost-benefit relationship that political actors face when choosing between feasible alternatives. According to Ferejohn and Pasquino (2001), rational political choice is a specific act chosen among the best acts available to the agent, given his beliefs and desires. In the context of competition among innovative policies, the literature states that the more competitive parties are, the highest is the likelihood of parties to suggest new social programs.

7 Downs (1999: 31) defines actors' rational behavior as follows: "a rational man who systematically making mistakes will stop doing so if (1) he figures out what is the mistake and (2) the cost of its elimination is less than its benefits".

8 In this context, ideology is understood as a model of thoughts and beliefs that explain individuals' general attitudes and their responsive relation with the society. This definition comes from Lowenstein (1953) cited in Gerring (1997), and differs from Downs' notion that considers ideology as a resource used by groups to reach power.

9 The present study considers both programs as distinct political actions, once they were created by distinct governmental bodies: mayors and the president. Therefore, these programs can be characterized as local and national policies.

10 The explanation of the rules for the adoption of PGRM is presented in the section "Explaining adoption to PGRM in São Paulo".

11 The principal reason is that there are notable differences among groups of political parties in many states of the Federation, and the focus on São Paulo allows one to control this variation. Other secondary reasons supporting this choice are: the state of São Paulo comprises half of the cases across the country; the municipal chambers and legislative assembly of São Paulo state were the institutions that presented the highest number of proposals for the creation of minimum wage programs; Campinas, the municipality that first created Bolsa Escola, is the unit of analysis that represents the temporal starting point of the study.

12 STATA: Release 10. Survival Analysis and Epidemiological Tables. STATA Press, 2007.

13 The Brazilian Workers' Party.

14 The Brazilian Social Democracy Party.

15 As none of the municipalities that created Bolsa Escola extinguished the program and subsequently recreated, it was not necessary to take the case out of the database and then insert it again.

16 Municipal Political Competition (1992, 1996 and 2000). Dichotomous variable defined as: i) competitive political system when a candidate wins the elections with less than $45 \%$ of the valid votes (assuming value $=1$ ), and ii) noncompetitive political system when a candidate wins municipal elections with more than $45 \%$ of the valid votes (assuming value $=0$ ). All the municipalities that had a second round were automatically classified as competitive.

17 Municipalities governed by PT: Dichotomous variable that informs the municipalities governed by PT that created Bolsa Escola, with the values $1=$ yes and $0=$ no. Municipalities governed by PSDB: Dichotomous variable that informs the municipalities governed by PSDB that created Bolsa Escola, with $1=$ yes and $0=$ no. 
18 Geographical Proximity: calculated by Moran Index, a statistical tool that provides a general measure of the spatial association between units distributed in a specific universe. In the models applied in this study, this variable estimates the spatial autocorrelation between the municipalities that created Bolsa Escola. The value close to 1 indicates a situation in which the decision to copy Bolsa Escola was significantly affected by the preceding choice made by geographically close municipalities. The value close to -1 indicates the opposite situation.

19 Metropolitan Municipality: represents the municipalities located in the three metropolitan areas of São Paulo state that created Bolsa Escola in subsequent years after their neighbors. The variable assumes the following values: "1" to those municipalities that created Bolsa Escola after their neighbors did so and "0" to municipalities that did not create Bolsa Escola subsequent to their neighbors.

20 Transfers from the Government to Poor Families: represents the percentage of inhabitants of São Paulo's municipalities whose family income depended more than $50 \%$ on cash transfers from the federal government between 1991 and 2000.

21 GDPperCapita: The used measure is the average of the municipal GDP per inhabitant, measured by the IBGE between 1997 and 2001.

22 The smallest municipality has a population of 800 inhabitants and the largest one (São Paulo capital) over 10 million people.

23 For a discussion on the population size of Brazilian municipalities, see Andrade and Serra (2001).

24 Interview with the author on March 28, 2008. Ana Lobato, Coordinator of the Study "Mapeamento dos Programas de Garantia de Renda Mínima no Brasil" ["Mapping the Minimum-Income Programs in Brazil"].

25 Interviews with the author in March and April, 2008. José Celso Júnior, Coordinator of the study "Mapeamento dos Programas de Garantia de Renda Mínima no Brasil" ["Mapping the Minimum-Income Programs in Brazil"]; Paula Galeano, former Chief of Office of the National Secretariat of Program Bolsa Escola. MEC/Federal Government; and Sônia Moreira, former Technical Manager of the Minimum-Income Program/Federal Government.

26 Political Alignment: dichotomous variable defined as follows: i) parties politically aligned with the federal government (value $=1$ ), and ii) parties not aligned politically with the federal government (value $=0$ ).

27 President's party: Dichotomous variable that evidences the municipalities governed by the party of the president (PSDB) that created PGRM, with values $1=$ yes and $0=$ no.

28 See endnote number 15 .

29 Municipal GDP: represented the average GDP of São Paulo's municipalities between 1999 and 2001.

30 This variable represents the average family income per inhabitant in 1991. For the statistical calculation, the index of 2002 for twenty municipalities that were emancipated after 1991 was considered.

31 For a discussion on the concept and types of accountability (vertical and horizontal), see O'Donnell (1991). 